\title{
Phase transitions in the borate minerals from the Kłodawa salt dome (central Poland) as indicators of temperature processes in salt diapirs
}

\author{
Jacek WACHOWIAK ${ }^{1, *}$ and Tomasz TOBOŁA ${ }^{1}$
}

1 AGH University of Science and Technology, Faculty of Geology, Geophysics and Environmental Protection, Al. A. Mickiewicza 30, 30-059 Kraków, Poland

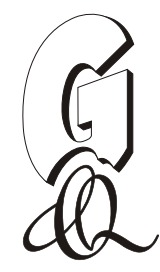

\begin{abstract}
Wachowiak, J., Toboła, T., 2014. Phase transitions in the borate minerals from the Kłodawa salt dome (central Poland) as indicators of temperature processes in salt diapirs. Geological Quarterly, 58 (3): 543-554, doi: 10.7306/gq.1170

The diapiric structures of the Polish Lowlands are tectonically deeply seated down to the autochthonous Zechstein strata at a depth of ca. $6 \mathrm{~km}$. In the process of deep burial and halokinetic diapirism, the salt rocks were subjected to diagenetic and metamorphic transformations, with the temperature being an essential factor. Considering the thermal gradient, a temperature of up to ca. $200^{\circ} \mathrm{C}$ can be achieved in the salt dome within a depth range from several hundred metres to $6 \mathrm{~km}$, which may lead to transformations of the majority of salt minerals. Phase transitions of two borate minerals - boracite and congolite from the Kłodawa salt dome - provide evidence for higher temperatures in the salt dome rocks. The authigenic euhedral crystals of those borate minerals display their external habitus in ambient temperature in the form of regular symmetry ( $F 43 c$ - pseudo-regular polyhedrons), whereas their internal structure is lower: orthorhombic (Pca2 1 ) for boracite and rhombohedral $\left(R 3_{c}\right)$ for congolite. The heating and cooling of boracite and congolite crystals show reversible phase transition. At a temperature of ca. $270^{\circ} \mathrm{C}$, boracite crystals change their symmetry: orthorhombic $\leftrightarrow$ cubic. In the case of congolite three reversible phase transitions within a temperature range of $50-339^{\circ} \mathrm{C}$ can be observed: rhombohedral $\leftrightarrow$ monoclinic $\leftrightarrow$ orthorhombic $\leftrightarrow$ cubic symmetry. Those phase transitions, confirmed experimentally in our study, clearly document at least local occurrences of temperatures exceeding $339^{\circ} \mathrm{C}$ in the Kłodawa salt dome.
\end{abstract}

Key words: boracite, congolite, phase transitions, temperature study, Zechstein, salt dome, Kłodawa.

\section{INTRODUCTION}

The rocks of salt diapirs were, and still are, subject to diagenetic and metamorphic transformations. The two basic factors of post-sedimentary transformations include pressure and temperature inside salt domes. Most of salt minerals are unstable in physical and chemical respects. For that reason, temperature increase from several tens to above one hundred ${ }^{\circ} \mathrm{C}$, as well as pressure increase, cause their diagenetic and metamorphic processes transformations (Borchert and Muir, 1964). Due to the geothermal gradient, rock salts in dome structures in a depth range from several hundred metres to $5-6 \mathrm{~km}$ are heated up to ca. $200^{\circ} \mathrm{C}$. The pressure caused by the halokinetic displacement of salt masses initiates the migration of heated solutions along a network of cracks/fractures and dislocations developed in the uplifting salt rock mass. Under the influence of temperature and pressure, diagenetic and metamorphic processes may take place. Some typical transformations observed in the temperature range discussed, include dehydration/thermal decomposition of carnallite. With increasing

\footnotetext{
* Corresponding author: e-mail: psgs@agh.edu.pl
}

Received: October 18, 2013; accepted: March 4, 2014; first published online: May 23, 2014 lithostatic pressure the temperature of dehydration/thermal instability increases from $83^{\circ} \mathrm{C}$ in an open system (Grube and Bräuning, 1938) to ca. $167^{\circ} \mathrm{C}$ (MPa $\sim 1000 \mathrm{~m}$ depth) in a closed system (Kern and Franke, 1986). Łaszkiewicz and LangierKuźniarowa (1966) proved dehydration temperatures of carnallite varying between 168 and $270^{\circ} \mathrm{C}$.

Depending on the accompanying minerals, carnallite can decompose at lower temperatures. For example at a temperature of ca. $72^{\circ} \mathrm{C}$, carnallite-kainite rock in the presence of halite and at $76^{\circ} \mathrm{C}$ in the absence of halite (Braitsch, 1971) transforms into sylvine-kieserite rock following the reaction (Borchert and Muir, 1964; Stańczyk-Stasik, 1976):

$$
\begin{gathered}
\mathrm{KCl} \cdot \mathrm{MgCl}_{2} \cdot 6 \mathrm{H}_{2} \mathrm{O}+\mathrm{KCl} \cdot \mathrm{MgSO}_{4} \cdot 3 \mathrm{H}_{2} \mathrm{O} \rightarrow \\
\rightarrow \mathrm{KCl}+\mathrm{MgSO}_{4} \cdot \mathrm{H}_{2} \mathrm{O}+\mathrm{MgCl}_{2} \cdot \mathrm{nH}_{2} \mathrm{O}
\end{gathered}
$$

or following Braitsch (1971):

$$
\begin{gathered}
\mathrm{KCl} \cdot \mathrm{MgCl}_{2} \cdot 6 \mathrm{H}_{2} \mathrm{O}+2\left(\mathrm{KCl} \cdot \mathrm{MgSO}_{4} \cdot 2.75 \mathrm{H}_{2} \mathrm{O}\right) \rightarrow \\
\quad \rightarrow 3 \mathrm{KCl}+2\left(\mathrm{MgSO}_{4} \cdot \mathrm{H}_{2} \mathrm{O}\right)+\mathrm{MgCl}_{2}+9.5 \mathrm{H}_{2} \mathrm{O}
\end{gathered}
$$

This process also exemplifies the release of considerable quantities of magnesium-bearing solutions as a result of salt mineral transformations. In addition, $\mathrm{Mg}$ can be generated from high evaporated relict sea water occurring in caverns, brine 
pockets and porous spaces as well as in fluid inclusions, mobilized during halokinetic movement.

Some evaporite minerals transform at much higher temperatures than is generally assumed. These include the phase transformations of borates from the boracite group (boracite, ericaite, congolite, trembatite), occurring in the Zechstein salt deposits. The characteristic common feature of those borates at room temperature $\left(25^{\circ} \mathrm{C}\right)$, is the pseudocubic shape of the crystals, as well as a lower symmetry of their internal structures: orthorhombic $\left(\mathrm{Pca}_{1}\right)$ in boracite and ericaite and rhombohedral $\left(R 3_{c}\right)$ in congolite and trembathite.

Experimental studies of pure synthetic phases of the endmember magnesium-ferrous borate components $-\mathrm{Mg}_{3} \mathrm{~B}_{7} \mathrm{O}_{13} \mathrm{Cl}$ and $\mathrm{Fe}_{3} \mathrm{~B}_{7} \mathrm{O}_{13} \mathrm{Cl}$ - indicated their reversible phase transitions with increase in temperature (e.g., Sueno et al., 1973; Dowty and Clark, 1973; Schmid and Tippmann, 1978). During heating to a temperature of ca. $264^{\circ} \mathrm{C}$, synthetic boracite $\mathrm{Mg}_{3} \mathrm{~B}_{7} \mathrm{O}_{13} \mathrm{Cl}$ transforms from orthorhombic (Pca2 ${ }_{1}$ ) to cubic (F43c). However, synthetic congolite $\mathrm{Fe}_{3} \mathrm{~B}_{7} \mathrm{O}_{13} \mathrm{Cl}$ was subjected to threephase transitions: from a rhombohedral structure $(\mathrm{R} 3 \mathrm{C})$ at room temperature to monoclinic $(\mathrm{Pc})$ at ca. $255^{\circ} \mathrm{C}$, to orthorhombic (Pca2 1 ) at ca. $270^{\circ} \mathrm{C}$ and finally to cubic $(F 43 \mathrm{c})$ at $\sim 336^{\circ} \mathrm{C}$.

Studies on natural boracite, trembathite and congolite crystals confirmed high-temperature phase transformations in the borates analysed, although those changes were documented for wider temperature ranges than those previously reported. Such wide ranges are due to the heterogeneous chemical composition of natural phases, with variable proportions of $\mathrm{Mg}^{2+}$ and $\mathrm{Fe}^{2+}$ (Burns and Carpenter, 1996, 1997).

Due to considerable temperature deviations of the phase transitions between natural and synthetic borates, it was the in- tention of the authors to determine experimentally the temperature values of the respective phase transitions occurring at various points within the natural boracite and congolite crystals from the Kłodawa salt dome (central Poland; Fig. 1). A study of the phase transitions and their temperatures in borate minerals can be a contribution to the determination of the thermal conditions existing in salt diapirs.

\section{GEOLOGICAL SETTING}

The Kłodawa salt dome is part of the anticlinal salt structure of Izbica Kujawska-Łęczyca, with a length of about $60 \mathrm{~km}$ and a width up to $3 \mathrm{~km}$, trending generally in NW-SE direction (Fig. 1). The salt structure is situated at the SW edge of the Kujawy part of the Mid-Polish Trough and it is the largest tectonic unit of this kind in the Polish Lowlands (e.g., Dadlez et al.,1995, 1998; Dadlez, 1997; Krzywiec, 2004, 2006).

In its central section, the Upper Permian Zechstein strata have pierced through the Mesozoic cover over a distance of ca. $26 \mathrm{~km}$ and a width of ca. $2 \mathrm{~km}$, creating the Kłodawa salt dome (Werner et al., 1960). In transverse cross-section, the dome has the form of a salt wall, ca. $6 \mathrm{~km}$ high, inclined to SW and widening with depth. In the horizontal plane the dome is elliptical.

In the lithostratigraphic profile of the Kłodawa salt dome (Fig. 2), evaporite and minor siliciclastic rocks of four cyclothems: PZ1 (Werra), PZ2 (Stassfurt), PZ3 (Leine) and PZ4 (Aller), have been distinguished and described (Werner et al., 1960; Charysz, 1973; Garlicki and Szybist, 1986; Tarka, 1992;

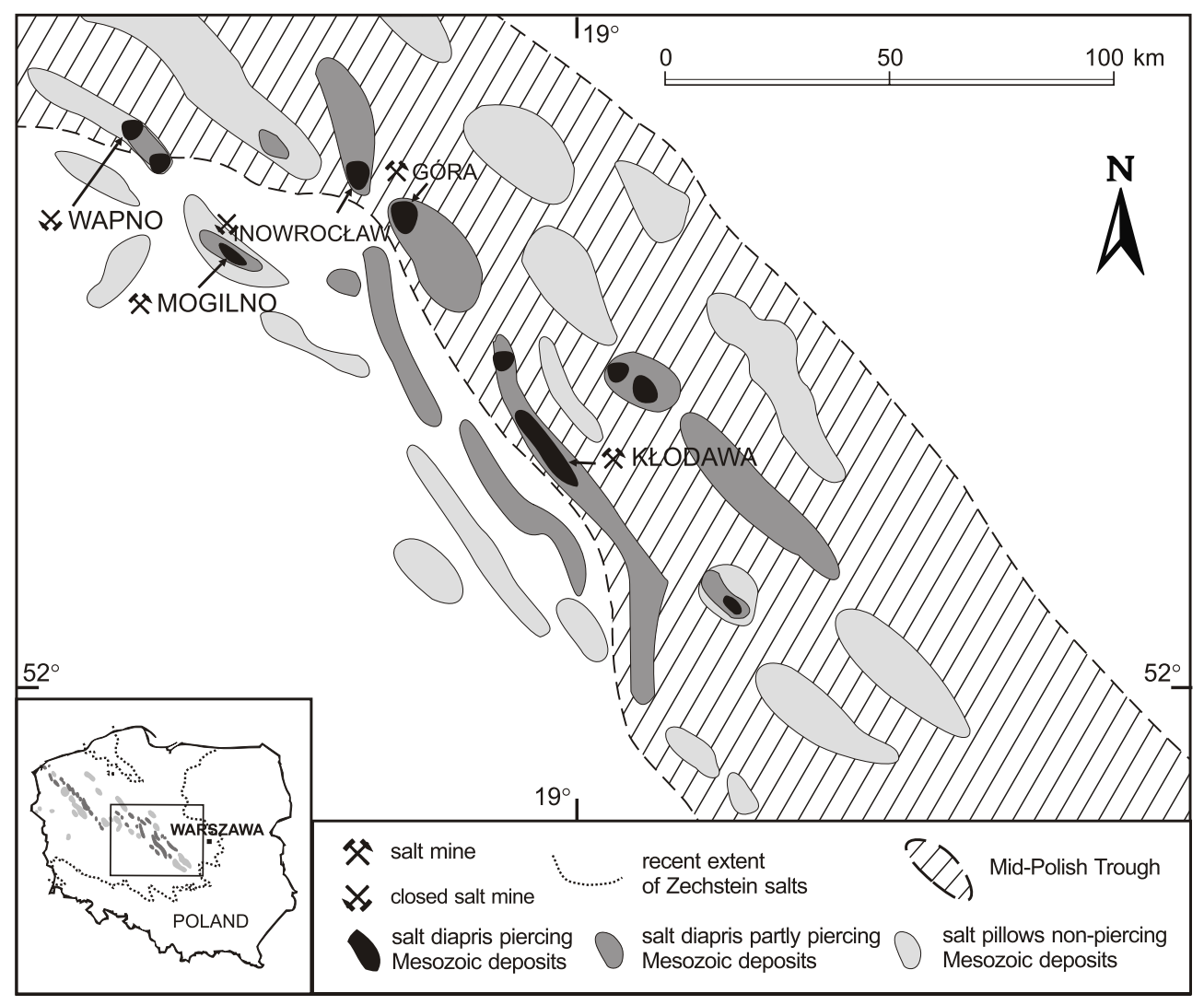

Fig. 1. Distribution of salt structures in the central part of the Mid-Polish Trough (from Garlicki and Szybist, 1986; Dadlez et al., 1998, modified by the authors) 


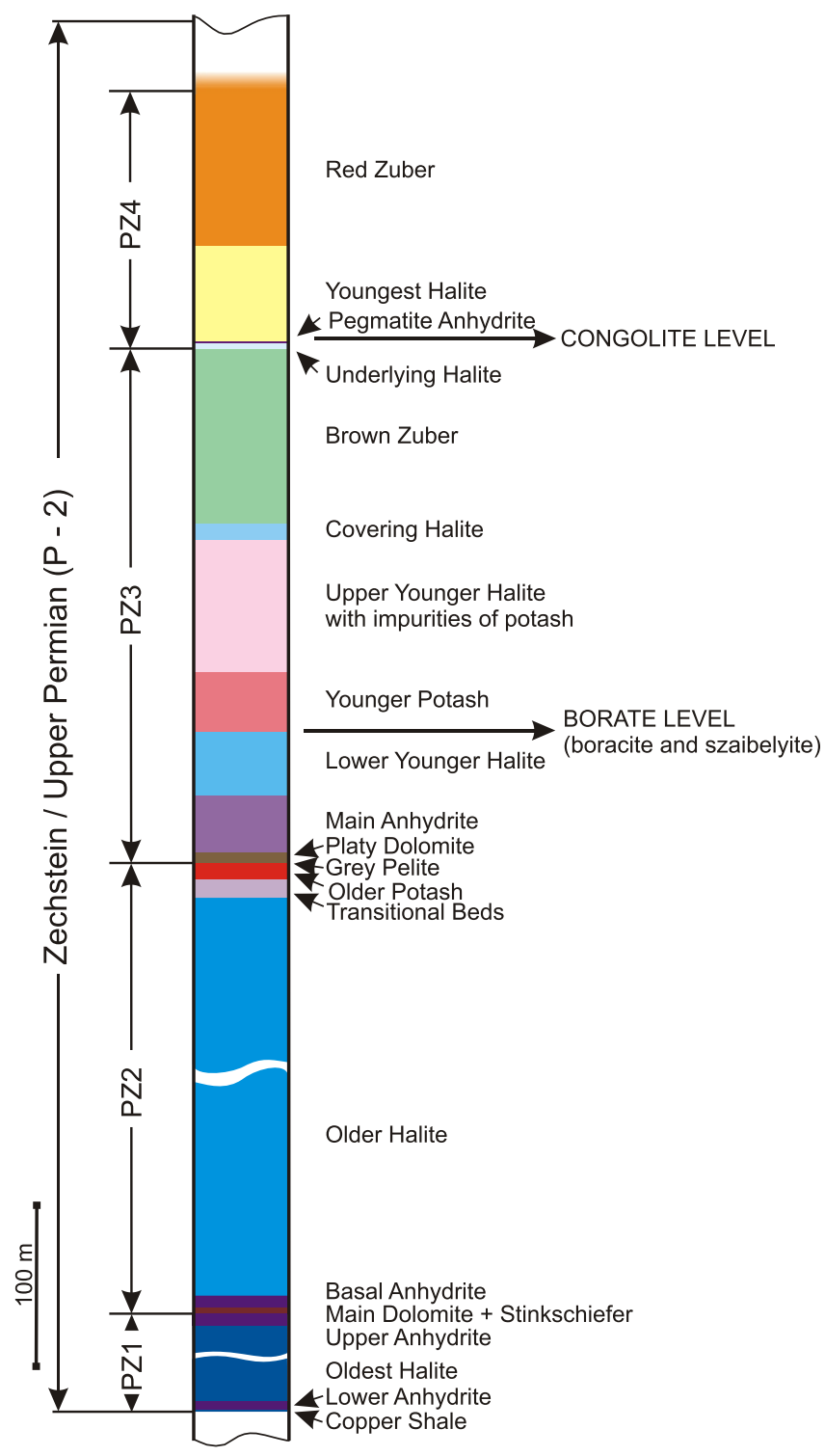

Fig. 2. A stratigraphic profile of the Kłodawa salt dome with boracite and congolite levels (from Charysz, 1973; Garlicki and Szybist, 1986, modified)

Burliga et al., 1995; Toboła and Natkaniec-Nowak, 2008; Burliga, 2011). The total thickness of the Zechstein salt deposits elevated in the Kłodawa dome is about $1,500 \mathrm{~m}$.

The lowest cyclothems (PZ1 and PZ2) and the lower part of PZ3 are mainly represented by rock salts, with a few layers of potash salts, anhydrite, claystone and carbonate. Higher Zechstein cyclothems, the middle and top beds of the PZ3 and the PZ4 cyclothem, are dominated by evaporite-terrigenous deposits (clayey salts or zubers), interbedded with rock salt and anhydrite.

Due to halokinesis (Trusheim, 1960), the salt beds have been strongly folded, while more rigid anhydrite and claystone beds were fractured. The anticline cores are composed of the PZ1 and PZ2 deposits, mainly rock salt. The limb sections contain younger deposits of the lower and middle part of the PZ3 cyclothem. Two main marginal anticlines are separated by a central syncline built of the youngest Zechstein deposits, i.e., of the upper sections of the PZ3 and PZ4 cyclothems (Werner et al., 1960).

\section{OCCURRENCE OF BORATE MINERALS IN THE KŁODAWA SALT DOME}

Four different borate minerals have been detected in the Kłodawa salt dome:

- boracite (Hanczke, 1969; Fijał, 1973; Wachowiak, 1998);

- szaibelyite (Fijał, 1970, 1973; Wachowiak, 1998);

- congolite (Wachowiak and Pieczka, 2012);

- trembatite (Wachowiak and Pieczka, 2012).

Boracite $\mathrm{Mg}_{3} \mathrm{~B}_{7} \mathrm{O}_{13} \mathrm{Cl}$ was found in the $\mathrm{PZ3}$ cyclothem deposits, in the carnallite-kieserite laminae of the top part of the Younger Lower Halite unit (Na3d) and in the kieserite-carnallite layers of the bottom part of the Younger Potash (K3) (Fig. 2). In both units, boracite occurs in the form of idiomorphic, colourless and transparent crystals, in shape comprising regular polyhedrons, chaotically dispersed within salt rocks.

Szaibelyite (ascharite) $\mathrm{MgBO}_{2}(\mathrm{OH})$ is associated with boracite in the carnallite-kieserite rocks of the PZ3 cyclothem. The mineral occurs as microcrystalline concentrations dispersed within the salt mass. Its crystals visible in SEM form needleshaped aggregates, several to several tens of micrometres long. Individual prismatic crystals are colourless and transparent.

Congolite $(\mathrm{Fe}, \mathrm{Mg}, \mathrm{Mn})_{3}\left[\mathrm{~B}_{7} \mathrm{O}_{13} \mathrm{Cl}\right]$ occurs in two units of the PZ4 cyclothem (Fig. 2):

- the Underlying Halite ( $\mathrm{Na} 4 \mathrm{aO})$, which is the lowermost unit of the PZ4 cyclothem. With a thickness about $3 \mathrm{~m}$, the layer is composed of white-grey-orange rock salt, with fine regular lamination with anhydrite flasers. The halite content ranges from 93 to $96 \%$. The Underlying Halite is underlain by the Brown Zuber of the PZ3 cyclothem, and overlain by the ca. $0.5 \mathrm{~m}$ thick Pegmatite Anhydrite (A4) bed.

- the lower part of the Youngest Halite (Na4) unit, dominated by pink salt. The Youngest Halite is underlain by the Pegmatite Anhydrite and overlain by the Red Zuber. The salt displays granoblastic structure, its blasts ranging between 3 and $10 \mathrm{~mm}$ across. Massive and chaotic texture is dominanting there, less often undulated or laminated. Congolite was found in the bottom layers, several metres above the contact with the Pegmatite Anhydrite (Wachowiak, 2010).

In both units congolite was found in trace amounts in the form of single crystals or crystal aggregates within the salt rocks. The crystals show pseudo-cubic and occasionally pseudo-tetrahedral shapes of yellow to purple-brown colour.

Trembathite $(\mathrm{Mg}, \mathrm{Fe}, \mathrm{Mn})_{3}\left[\mathrm{~B}_{7} \mathrm{O}_{13} / \mathrm{Cl}\right]$ was detected together with congolite as double-phase intergrowths of pseudo-cubic shape. These are described together with those of congolite. The presence of a mineral with the chemical composition $\left(\mathrm{Mg}_{1.57} \mathrm{Fe}_{1.36} \mathrm{Mn}_{0.07}\right)_{{ }_{23}} \mathrm{~B}_{7} \mathrm{O}_{13} \mathrm{Cl}$ in some crystal segments (or sectors) was identified on the basis of electron microprobe analysis (Wachowiak and Pieczka, 2012).

\section{SAMPLING, EXPERIMENTAL FRAMEWORK AND ANALYTICAL METHODS}

The samples were collected in the Kłodawa Salt Mine at a depth of $750 \mathrm{~m}$ : fifteen samples, weighing ca. $6 \mathrm{~kg}$ each, from the Underlying Salt and the Youngest Rock Salt in three workings, within the congolite zones, and seven samples, weighing ca. $6 \mathrm{~kg}$ each, in two workings, from the Lower Younger Halite unit (Na3d) and the bottom part of the Younger Potash (K3) that 
may contain boracite. From each sample, 5-kg-aliquots were dissolved in distilled water (until reaction with $\mathrm{AgNO}_{3}$ disappeared). The water - insoluble residuum was dried at the ambient temperature $\left(\sim 25^{\circ} \mathrm{C}\right)$ and weighed. Quantitative and qualitative analyses were conducted with respect to the hardly soluble minerals. Several tens of boracite and congolite crystals were selected for further studies.

Five boracite crystals and five congolite crystals, from 0.4 to $0.9 \mathrm{~mm}$ each, were mounted with Super Glue on glass plates, thinned to a thickness of about $35 \mu \mathrm{m}$, double polished, and coated with carbon for electron microprobe analysis. The analyses were performed at the Inter-Institute Analytical Complex for Minerals and Synthetic Substances of the University of Warsaw, using a Cameca SX 100 electron microprobe operating in the wavelength-dispersive (WDS) mode, with the following parameters: accelerating voltage $15 \mathrm{kV}$, beam current $10 \mathrm{nA}$, beam diameter $2 \mu \mathrm{m}$, peak count-time $20 \mathrm{~s}$, background time $10 \mathrm{~s}$. The minimum detection limits for the elements analysed were: 0.04 wt. $\%$ for $\mathrm{Mg}, 0.16$ wt. $\%$ for $\mathrm{Fe}$ and $\mathrm{Mn}$, and 0.08 wt. $\%$ for $\mathrm{Cl}$. The $\mathrm{B}_{2} \mathrm{O}_{3}$ content was calculated from stoichiometry, assuming normalization of the analyses in relation to $3 \mathrm{Mg}$ for boracite, $3(\mathrm{Fe}+\mathrm{Mn}+\mathrm{Mg})$ for congolite, and $14(\mathrm{O}, \mathrm{Cl})$ atoms per formula unit (apfu).

After electron microprobe analysis, carbon was removed from the boracite and congolite crystals. The crystals were subjected to optical tests, in transmitted light under an Olympus $B X-12$ polarizing microscope. Later, thin plates of particular crystals were detached from the glass plates and subjected to thermal tests under a Nikon Eclipse E600 polarizing microscope, equipped with a replaceable THMSG 600 freezing-heating table with Linkam accessories, allowing for the measurement of temperatures from -196 to $600^{\circ} \mathrm{C}$, with the accuracy of $0.1^{\circ} \mathrm{C}$. Before the measurements started, the temperature was calibrated using pure $\mathrm{CO}_{2}$ synthetic inclusions $\left(\mathrm{Tm}=-56.6^{\circ} \mathrm{C}\right)$ and the known homogenization temperature of pure $\mathrm{H}_{2} \mathrm{O}$ inclusions. The heating rate of the samples was $1^{\circ} \mathrm{C} / \mathrm{min}$.

\section{RESULTS}

\section{BORATE MINERAL CHARACTERISTICS}

Boracite. Boracite was identified in the residuum of the hardly water - soluble mineral fraction in four of seven samples from the carnallite-kieserite laminae of the Younger Lower Halite unit and in three samples collected from the kieserite-carnallite rock of the Younger Potash (K3). The content of the hardly soluble residuum in those samples ranges from 0.4 to $1.1 \mathrm{wt} . \%$. Monocrystalline anhydrite, constituting from 70 to $95 \%$ of the mineral substance volume, is the dominat hardly soluble mineral. The boracite content ranges from 5 to 20 vol.\%. In two samples collected from the kieserite-carnallite rock, small quantities of szaibelyite (ca. 1-2\%) were found. In addition, trace quantities of euhedral quartz and pyrite crystals were detected.

Boracite occurs in the form of authigenic, idiomorphically developed crystals, with the shape of pseudo-regular polyhedra, mostly pentagonal dodecahedra. The crystals are colourless and transparent, with strong lustre (Fig. 3). Their size ranges from tenths of a millimetre to ca. $1.5 \mathrm{~mm}$ across. The mineral is colourless in thin sections, with grey and white-grey interference colours of the first order. Marginal parts of crystals contain polysynthetic lamella twinning, perpendicular to the crystal edges

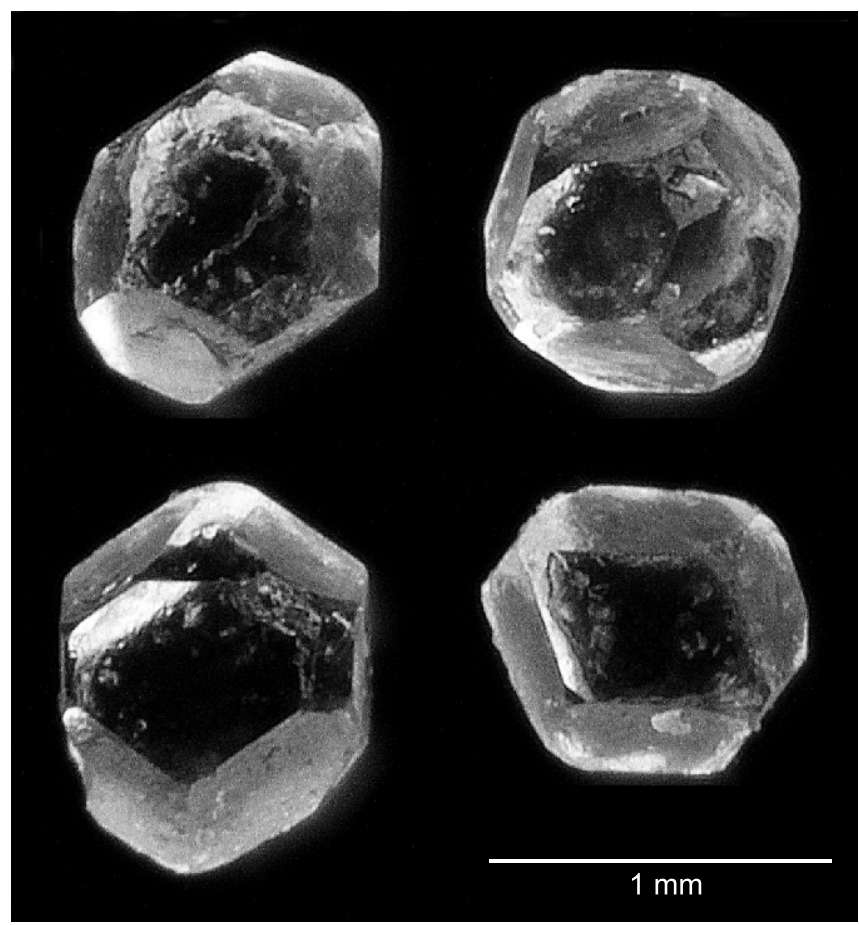

Fig. 3. Boracite crystals from carnallite-kieserite layers (Younger Potash - K3, Kłodawa salt dome)

(Fig. 4A-C). The spot chemical composition of selected points in the crystals B1, B2, B3 is given in Appendix 1*: $\mathrm{Mg}, \mathrm{Fe}$ and $\mathrm{Mn}$ displayed as oxides ( $\mathrm{MgO}, \mathrm{FeO}, \mathrm{MnO})$. The $\mathrm{MgO}$ content of these crystals varies between 25.46 and 30.96 wt. \%. $\mathrm{Fe}^{2+}$ replacing $\mathrm{Mg}$ ranges from 0.00 to $7.42 \mathrm{wt} . \%$ of $\mathrm{FeO}$, while the $\mathrm{Mn}^{2+}$ content ranges from 0.00 to $0.25 \mathrm{wt} . \%$ of $\mathrm{MnO}$. The $\mathrm{Fe}$ and $\mathrm{Mn}$ contents are increased in the centre and at the edges of the crystals (Appendix 1; Figs. 4B, B' and 5A-D). Nevertheless, in most of the microprobe analyses, the contents of $\mathrm{Fe}$ and $\mathrm{Mn}$ do not exceed the detection thresholds of 0.16 wt. $\%$. The average chemical formula of most of the boracite crystals can be determined as $\left(\mathrm{Mg}_{2.97} \mathrm{Fe}_{0.03} \mathrm{Mn}_{0.004}\right) \mathrm{B}_{7} \mathrm{O}_{13} \mathrm{Cl}$. Those small admixtures of $\mathrm{Fe}$ and $\mathrm{Mn}$ influenced, however, the temperature of boracite phase transitions.

Insignificant differences in the chemical composition of particular zones in the crystals are hardly visible in BSE images (Fig. 4A', B', C'). In some crystals, Fe enrichment is seen in the form of lighter bands (Fig. 4B'). The chemical composition of the peripheral zone, enriched in $\mathrm{Fe}$ (crystal B2, point 4), is expressed by the formula $\left(\mathrm{Mg}_{2.86} \mathrm{Fe}_{0.13} \mathrm{Mn}_{0.01}\right) \mathrm{B}_{7} \mathrm{O}_{13} \mathrm{Cl}$.

\section{THERMAL STUDIES OF BORACITE CRYSTALS}

When boracite crystals (B-2 and B-3) were heated (Fig. 5), the optical properties started to change, becoming isotropic at a temperature of $210^{\circ} \mathrm{C}$. This is attributed to a change in the crystalline lattice from orthorhombic to cubic symmetry. At higher temperatures, a slow and gradual isotropization followed, first at points and then irregularly in various parts of the crystals (Fig. $5 B, F$ ). From the temperature of $264^{\circ} \mathrm{C}$, specified as the point of synthetic boracite phase transition (e.g., Sueno et al., 1973; Schmid and Tippmann, 1978), a fast, concentric-zonal extinction of interference colours continued (Fig. 5C, G). In the narrow temperature range of $269-270^{\circ} \mathrm{C}$, the main phase transition 

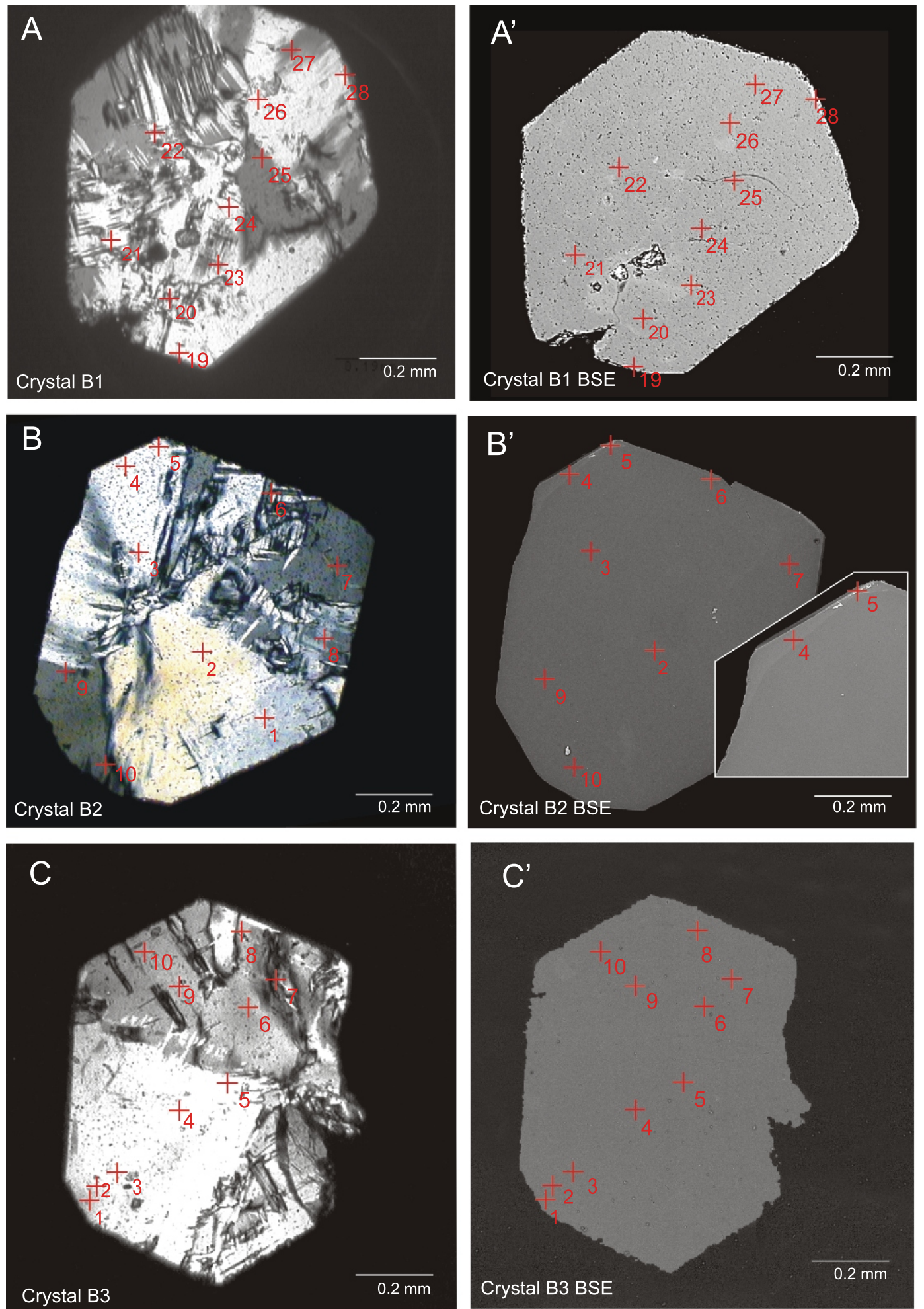

Fig. 4. Representative types of boracite crystals from the Kłodawa salt dome

A, B, C - microscope images under crossed polars;

A', B', C' - BSE images; numbers indicate microprobe analyses

process occurred. About $98 \%$ of crystals were subjected to isotropization. The interference colours were observed only in central and peripheral crystal bands, mostly in those enriched in $\mathrm{Fe}$ (Fig. 5D, H). Total isotropization took place at $271^{\circ} \mathrm{C}$. During slow cooling of the crystals, the reverse structural transformation, from cubic to orthorhombic symmetry, was detected at similar temperatures.
The chemical compositions of particular crystal points with phase transition temperatures at those points (Appendix 1) indicate clearly that a small difference in the Fe content causes a change of the phase transition temperature even by several ${ }^{\circ} \mathrm{C}$. The concentric-zonal extinction of interference colours (isotropization) at various temperatures, which depends on the chemical composition of the zones (Appendix 1 and Fig. 5) empha- 

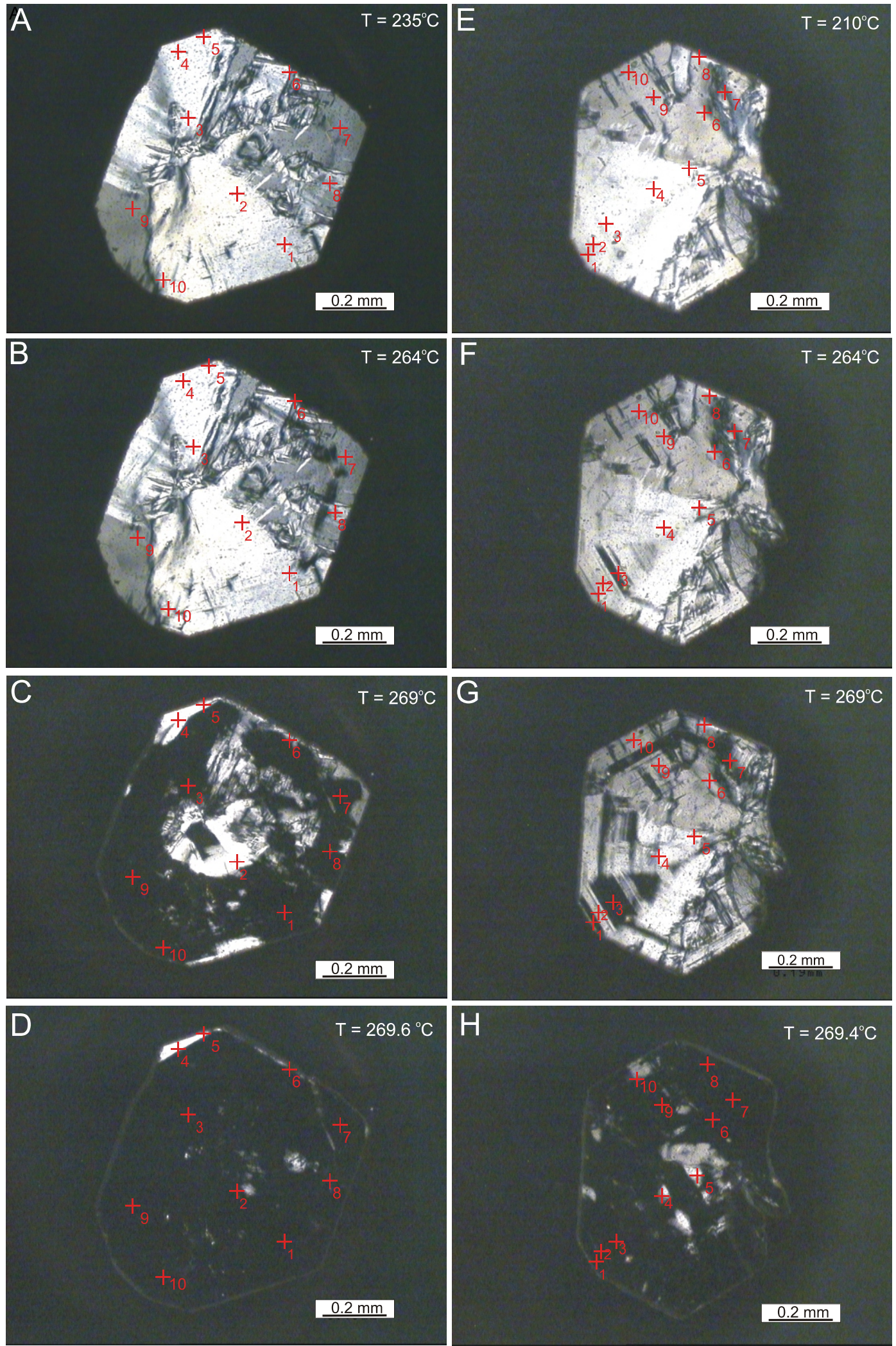

Fig. 5. Microscope images of boracite crystals upon heating (crossed polars) A-D - crystal B2, E-H - crystal B3; for other explanations see Figure 4 
sizes and demonstrates the subtle concentric-zonal changeability of the chemical composition of some of the boracite crystals under investigation.

Congolite. Congolite crystals were identified in five out of 15 samples. Two samples were collected from the Underlying Halite and three samples of the Youngest Halite (Pink Salt) at a distance of 3-6 m from the top of the Pegmatite Anhydrite. Congolite crystals were found in trace quantities, from several to about a dozen crystals in each sample, varying between 0.05 and $1.1 \mathrm{~mm}$ in size, depending on the sample. This mineral occurs as an euhedral, well-developed, slightly transparent, yellow, light purple, purple-brown to brown crystals (Figs. 6 and 7). The cubic and tetrahedral shapes of the crystals, with truncated edges and corners, are often observed. Those are paramorphoses of the low-temperature varieties of congolite $(\alpha)$, with rhombohedral symmetry in ambient temperature, after the high-temperature variety $\beta$ which has a cubic structure above $336^{\circ} \mathrm{C}$ (hextetrahedral symmetry class, F43c space group) (Schmid and Tippmann, 1978; Burns and Carpenter, 1996). Under the microscope, the congolite crystals are transparent and colourless in thin sections at room temperature. Optical tests conducted in convergent light indicated that it was optically a uniaxial mineral $(-)$, which unequivocally distinguished the mineral as congolite from the biaxial ericaite (Wachowiak and Pieczka, 2012).

In crystals oriented parallel to the (001) plane, one can see polysynthetic lamella twinning. In polarized light, the concentric-zonal or sectoral-zonal structures are clearly visible, reflecting the diverse chemical compositions of the crystals (Fig. $8 \mathrm{~A}-\mathrm{C}$ ). The sectors (subcrystals) are oriented at various angles with respect to each other, which is demonstrated by a wide range of interference colours, from first order grey of the to the second order blue and green. Polysynthetic twinning crossing at $90^{\circ}$ is clearly visible (Fig. $8 \mathrm{C}$ ).

Point chemical analyses by microprobe and BSE images show the diverse chemical composition of the crystals investigated (Appendixes 2 and 3; Fig. $8 A^{\prime}-C^{\prime}$ ). This is due to the fact that congolite forms solid solutions, which at each point of a crystal have a different combination of $\mathrm{Fe}, \mathrm{Mg}$, and $\mathrm{Mn}$ contents, from $\left(\mathrm{Fe}_{2.8} \mathrm{Mg}_{0.12} \mathrm{Mn}_{0.08}\right) \mathrm{B}_{7} \mathrm{O}_{13} \mathrm{Cl}$ to $\left(\mathrm{Fe}_{1.51} \mathrm{Mg}_{1.42} \mathrm{Mn}_{0.07}\right) \mathrm{B}_{7} \mathrm{O}_{13} \mathrm{Cl}$.

The crystal C-2 (Fig. 8A, $\mathrm{A}^{\prime}$ ) is an aggregate of several subcrystals, each with one or several crystallisation centres.

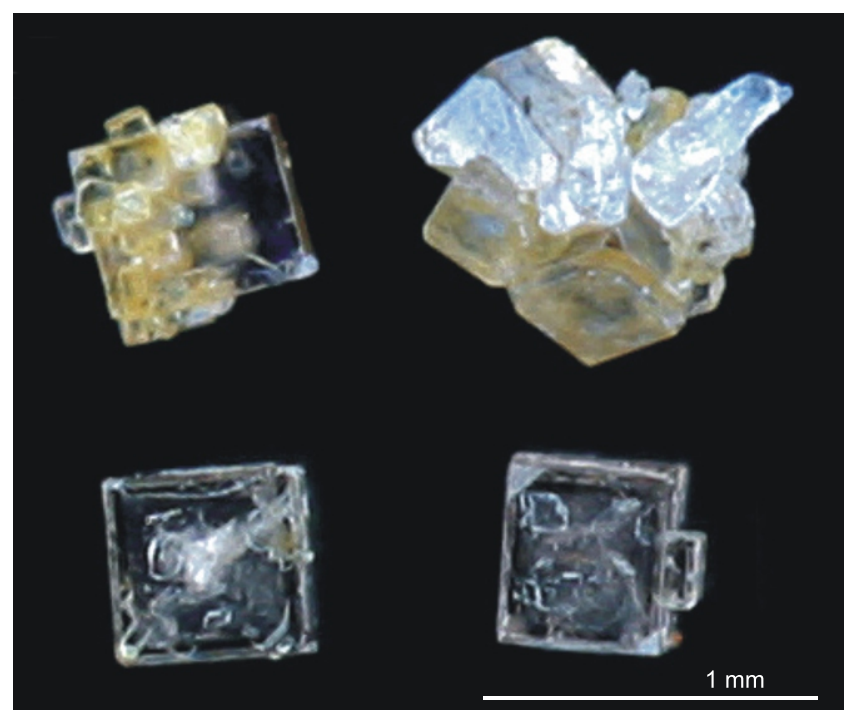

Fig. 6. Congolite crystals from Youngest Halite (Na4) strata, Kłodawa salt dome

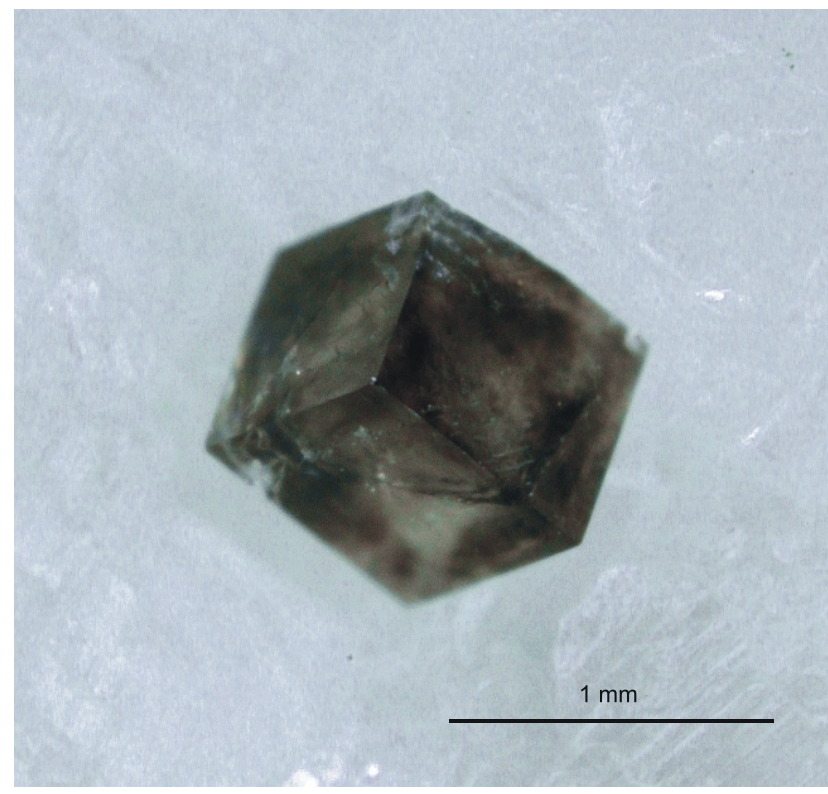

Fig. 7. Congolite crystal within rock salt (Youngest Halite - Na4; Kłodawa salt dome)

The centres (nuclei) have maximum iron enrichment and minimum magnesium content. A typical chemical content of the nucleus at the point $\mathrm{C}-2 / 23$ can be expressed by the formula $\left(\mathrm{Fe}_{2.77} \mathrm{Mg}_{0.15} \mathrm{Mn}_{0.08}\right) \mathrm{B}_{7} \mathrm{O}_{13} \mathrm{Cl}$. The zones which are depleted in Fe are developed around the centres, and the typical formula at $\mathrm{C}-2 / 7$ is $\left(\mathrm{Fe}_{2.09} \mathrm{Mg}_{0.85} \mathrm{Mn}_{0.06}\right) \mathrm{B}_{7} \mathrm{O}_{13} \mathrm{Cl}$. These are followed by zones strongly enriched in $\mathrm{Mg}$; their chemical content is similar to that of point C-2/61: $\left(\mathrm{Fe}_{1.72} \mathrm{Mg}_{1.23} \mathrm{Mn}_{0.05}\right) \mathrm{B}_{7} \mathrm{O}_{13} \mathrm{Cl}$.

The crystal C-5 (Fig. 8B, B') has a simple zonal structure, with the internal zone enriched in $\mathrm{Fe}$, the diagonal zoning of which is a characteristic feature of that crystal and can also be observed in many other crystals. The chemical differentiation develops by bands, in parallel to the diagonal $X Y$ of the thin section. The maximum iron content was observed in the central part of the crystal, at points $22,32,33$, and 41 , corresponding to a chemical formula of $\left[\left(\mathrm{Fe}_{2.8} \mathrm{Mg}_{0.12} \mathrm{Mn}_{0.08}\right) \mathrm{B}_{7} \mathrm{O}_{13} \mathrm{Cl}\right]$. The highest magnesium content was determined at the edge zones and corners of the crystal. At point 44, the magnesium and iron contents are comparable $\left[\left(\mathrm{Fe}_{1.48} \mathrm{Mg}_{1.44} \mathrm{Mn}_{0.08}\right) \mathrm{B}_{7} \mathrm{O}_{13} \mathrm{Cl}\right]$.

The crystal C-6 (Fig. 8C, C') shows simple zoning, without sectoral subdivision. In the crystal centre there are several crystallisation nuclei enriched in $\mathrm{Fe}$, with the composition $\left(\mathrm{Fe}_{2.29} \mathrm{Mg}_{0.45} \mathrm{Mn}_{0.26}\right) \mathrm{B}_{7} \mathrm{O}_{13} \mathrm{Cl}$, (point 28); covered by large crystallization area, rich in magnesium; at the point C-6/31, the composition is $\left(\mathrm{Fe}_{1.95} \mathrm{Mg}_{0.96} \mathrm{Mn}_{0.09}\right) \mathrm{B}_{7} \mathrm{O}_{13} \mathrm{Cl}$. The marginal parts of the crystal are also Fe-enriched: $\left(\mathrm{Fe}_{2.51} \mathrm{Mg}_{0.30} \mathrm{Mn}_{0.19}\right) \mathrm{B}_{7} \mathrm{O}_{13} \mathrm{Cl}$ at point C-6/46.

THERMAL STUDIES OF CONGOLITE CRYSTALS

When the crystal C-5 was heated (Figs. 9 and 10), a change in its optical properties (interference colours) began to be observed at $50^{\circ} \mathrm{C}$, at the Mg-rich edges and corner zones (Fig. 9B). With increasing temperature, the area of transformation gradually expanded towards the Fe-rich crystal centre (Fig. 9C, D). Up to a temperature of $210^{\circ} \mathrm{C}$ (Fig. 9D) the crystal segments and zones enriched in magnesium underwent structural transformation displayed by the change of interference colours from blue, violet of the second order to grey and white-grey of the first order. This change can be attributed to the transition from 

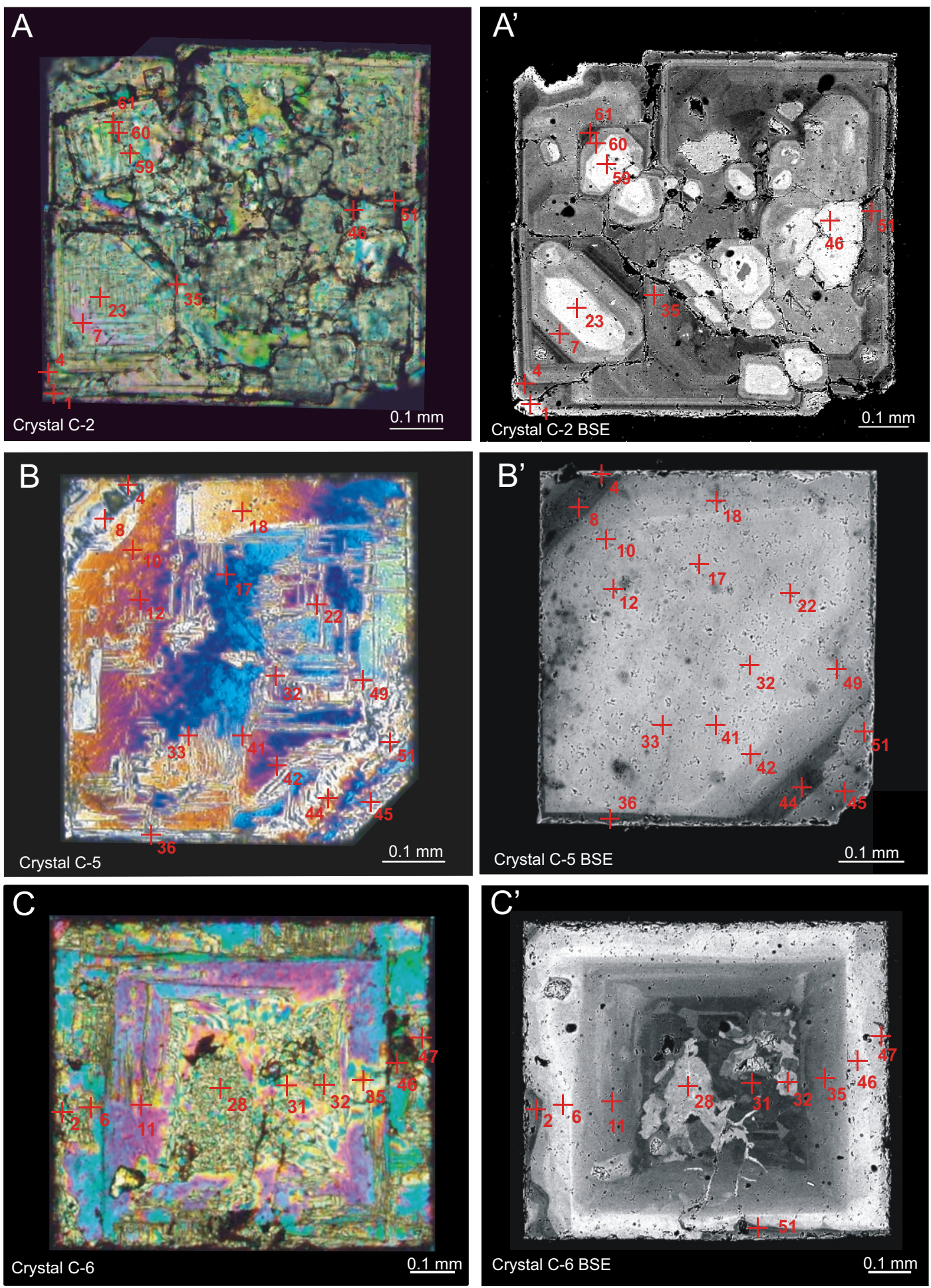

Fig. 8. Representative types of congolite crystal, oriented parallel to the (001) plane

A, B, C-microscope images under crossed polars; A', B', C' - BSE images; for other explanations see Figure 4

rhombohedral to monoclinic symmetry, reported in synthetic congolite crystals by Schmid and Tippman (1978).

Within the temperature range of $210-270^{\circ} \mathrm{C}$ (Fig. 9D-F) two phase transitions were observed at the same time:

- in the parts of the crystal enriched in magnesium, from monoclinic symmetry to orthorhombic;
- in the band with the chemical composition similar to pure congolite $\left[\left(\mathrm{Fe}_{2.8} \mathrm{Mg}_{0.12} \mathrm{Mn}_{0.08}\right) \mathrm{B}_{7} \mathrm{O}_{13} / \mathrm{Cl}\right.$ at point 41$]$, from rhombohedral symmetry to monoclinic one at $230-255^{\circ} \mathrm{C}$, followed by orthorhombic at about $260-270^{\circ} \mathrm{C}$.

At $290^{\circ} \mathrm{C}$, crystal isotropization started, proceeding from bands and sectors with the chemical composition enriched in $\mathrm{Mg}$ towards the central area which is richer in Fe (Fig. 10A-E). 

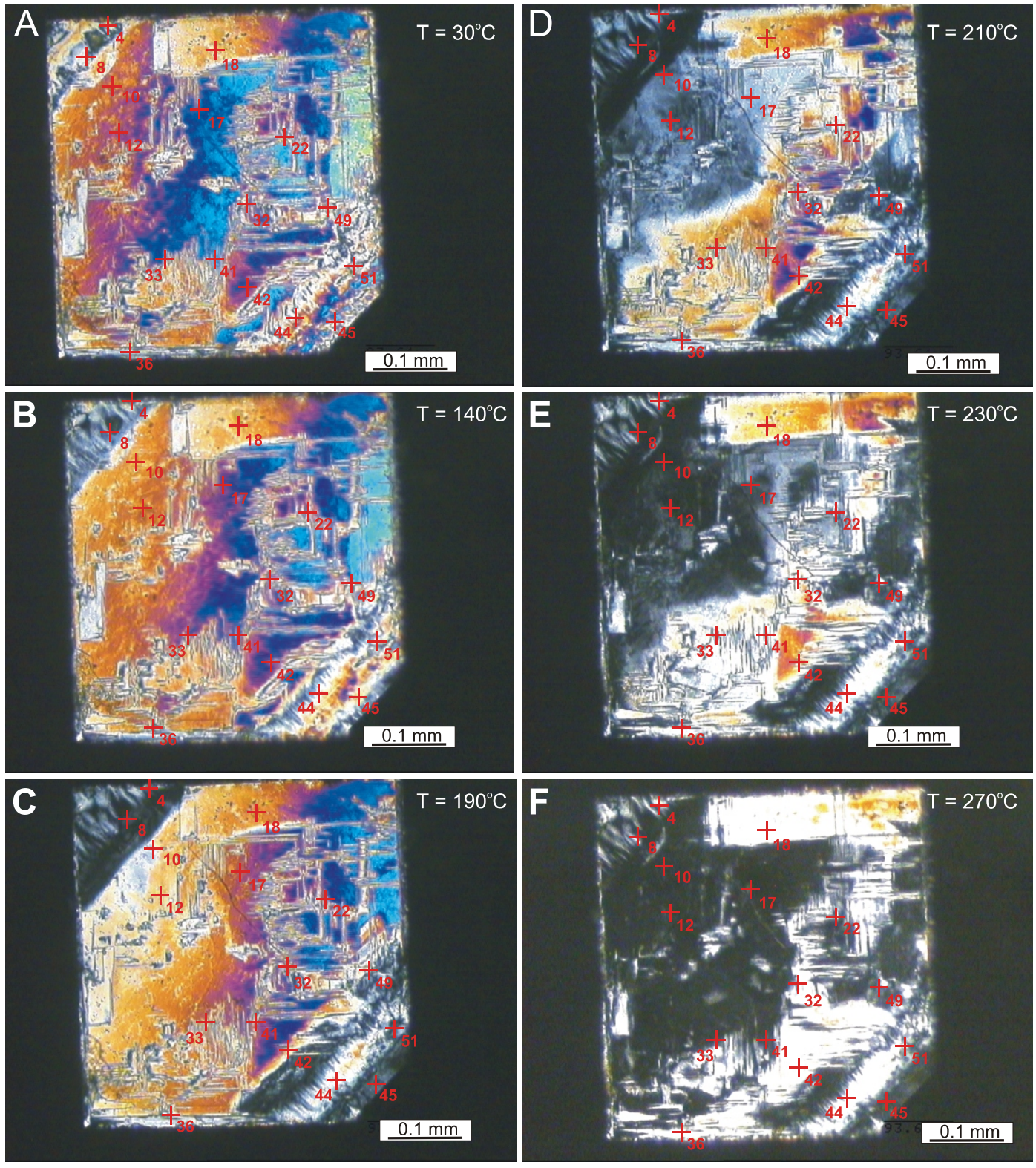

Fig. 9. Microscope images of congolite crystal C-5 upon heating (crossed polars)

$\mathrm{T}=30-270^{\circ} \mathrm{C} ;$ for other explanations see Figure 4

The zones of the highest Fe content (points 32 and 41; Appendix 3 ) were subjected to complete transition to structures with cubic symmetry $338^{\circ} \mathrm{C}$ (Fig. 10F).

Observations of phase transformations in crystals C-2 and C-6 supported the process described above and, in particular, the clear dependence of the transformation temperature on hemical composition (Fe to $\mathrm{Mg}$ ratio). The temperature differences of those transformations at points of similar chemical composition in various crystals ranged within $2-8^{\circ} \mathrm{C}$.

During the thermal studies, we observed clear changes in the optical properties (double refraction) of congolite, during the transition from rhombohedral symmetry to monoclinic, comprising a change in maximum interference colours from blue and green of second order to first order grey and white-grey. The course of those transitions developed within a wide range of temperatures, from 50 to about $255^{\circ} \mathrm{C}$. The transitions of monoclinic symmetry into orthorhombic were difficult to observe owing to the similar optical properties of those phases (similar in- terference colours). The third transition to regular symmetry was easily noticeable in particular crystal sectors and zones owing to a clear disappearance of interference colours in narrow temperature ranges.

\section{INTERPRETATION AND DISCUSSION}

In natural crystals of the borates from the Kłodawa salt dome, phase transitions developed within much wider temperature ranges than in the case of pure synthetic crystals. In addition, the transformation temperature was slightly higher (by several ${ }^{\circ} \mathrm{C}$ ).

In synthetic $\mathrm{Mg}_{3} \mathrm{~B}_{7} \mathrm{O}_{13} \mathrm{Cl}$, the phase transition from orthorhombic structure $\left(\mathrm{Pca}_{1}\right)$ to cubic structure $(\mathrm{F} 43 \mathrm{c})$ took place at ca. $264^{\circ} \mathrm{C}$ (e.g., Sueno et al., 1973; Schmid and Tippmann, 1978). In natural boracite crystals from the Kłodawa salt deposit 

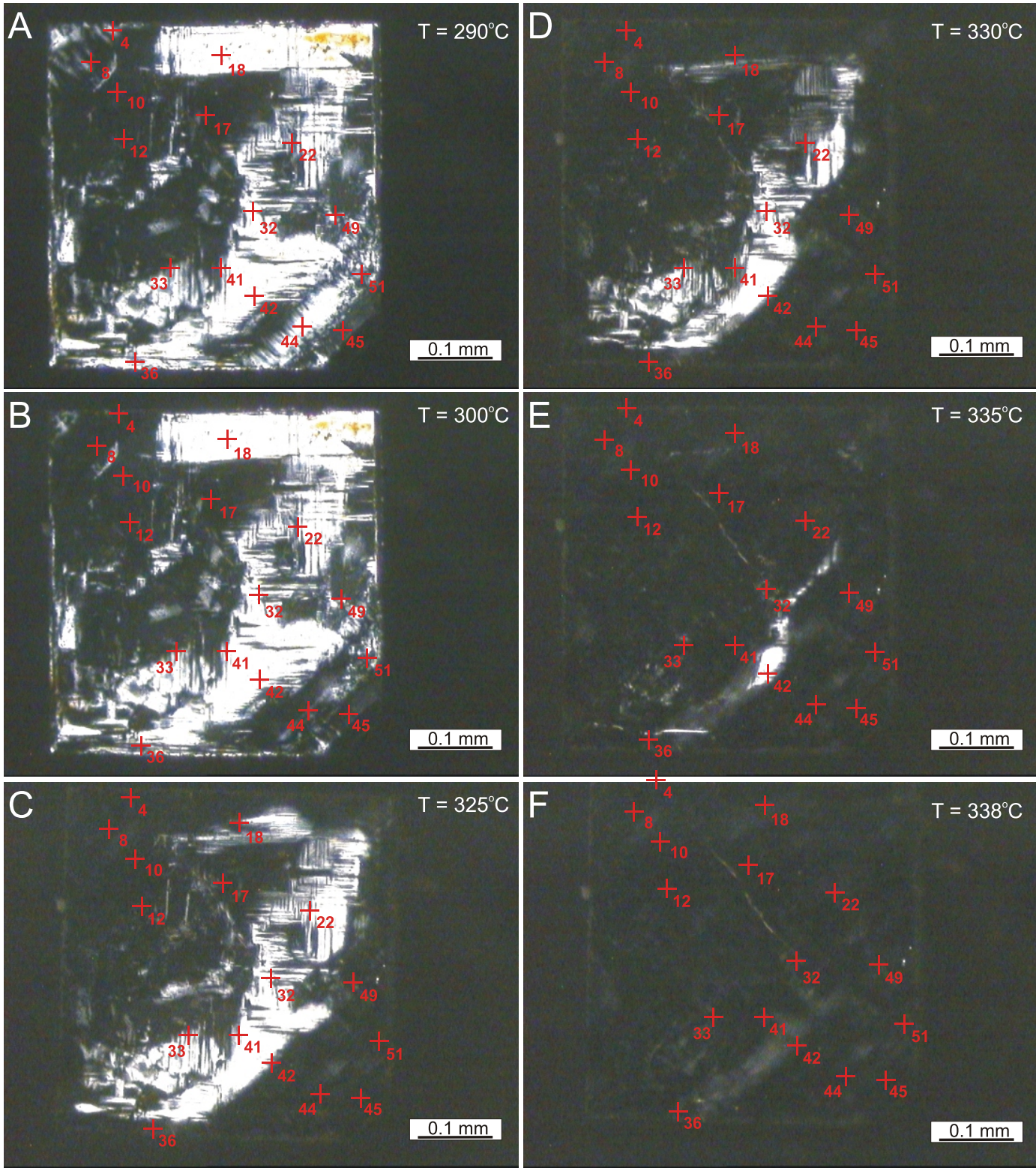

Fig. 10. Microscope images of congolite crystal C-5 upon heating (crossed polars)

$\mathrm{T}=290-338^{\circ} \mathrm{C} ;$ for other explanations see Figure 4

a gradual change of optical properties during heating (loss of interference colours) was noted within a wide temperature range of $210-270^{\circ} \mathrm{C}$. Nevertheless, the main phase transition process, i.e. from orthorhombic structure (Pca2 1 ) to cubic (F43c), took place at a very narrow temperature range of $269-270^{\circ} \mathrm{C}$ (Fig. 5D, H).

In the synthetic congolite crystals $\left(\mathrm{Fe}_{3} \mathrm{~B}_{7} \mathrm{O}_{13} \mathrm{Cl}\right)$, the final phase transition from orthorhombic to cubic symmetry was detected at ca. $336^{\circ} \mathrm{C}$. In the natural congolite crystals from Kłodawa the isotropization process, which determines the minimum temperature of transition from orthorhombic structure $\left(\mathrm{Pca}_{1}\right.$ ) to cubic (F43c), was developed within $290-338^{\circ} \mathrm{C}$.

The above phase transition temperature ranges closely match the results of the research conducted on natural boracites and congolite from the borate deposits of Sussex, New Brunswick, Canada (Burns and Carpenter, 1996, 1997).
The reasons for a considerable expansion of the temperature ranges in which phase transitions occurred in congolite were the differences in the chemical composition of particular points, zones, and sectors in the crystal. The ratio of the $\mathrm{Fe}^{2+}$ and $\mathrm{Mg}^{2+}$ ions plays a principal role in the phase transition process. The transition temperature increases with an increase in Fe content in the mineral. A significant role at higher temperatures of phase transitions can also be played by a slight admixture of $\mathrm{Mn}$.

The preserved regular habit of boracite and congolite crystals, typical of high-temperature $\beta$ varieties, and simultaneously revealing their lower internal symmetry, indicate that these minerals originated by epigenetic recrystallisation during diagenesis or metamorphism of salt rocks at high temperatures. The $\beta$-boracite crystals developed above $270^{\circ} \mathrm{C}$, and the $\beta$-congolite crystals recrystallised above $338^{\circ} \mathrm{C}$. These are minimum tem- 
peratures, determined on the basis of structural transitions of those minerals, whereas the temperatures occurring in the salt dome could have been much higher. In the subsequent stages of diapir formation, as a result of gradual cooling of the upper sections of the dome, borate crystals underwent a transition of internal structure to lower symmetry, though preserving the cubic habit fixed at high temperatures. What has remained after phase transition is the frequently observed presence of typical microstructures, resembling polysynthetic lamella twinning (Figs. 4A and $8 \mathrm{C}$ ).

The development, geochemical composition, form, and diverse local distribution of the boracite and congolite in the Kłodawa salt dome indicate different origins for these minerals.

Boracite is associated with szaibelyite and their occurrence is restricted to the carnallite-kieserite layer of the Younger Potash and the underlying Lower Younger Halite. Both boracite and szaibelyite are secondary minerals, formed during metamorphism of primary borate minerals, such as e.g. hydroboracite, kaliborite or pinnoite (Fijał, 1973; Yarzhemskiy, 1984). In the early stage of diagenesis and during deep burial, lowtemperature $\alpha$-boracite (Borchert and Muir, 1964) could recrystallise from primary hydrated borates. In subsequent phases of diapir uplift, as a result of the development of cracks and tectonic dislocations reaching the pre-Zechstein basement (Znosko, 1957; Krzywiec, 2004), and owing to steep stratification of salt layers, geochemical as well as thermal transformations of salt rocks occurred under the influence of migrating, hot highly concentrated brines, probably also including hydrothermal circulation originating from the pre-Zechstein basement. In addition to fissures and tectonic dislocations, specific "thermal pathways" may have been provided by cracked and crushed layers of anhydrite, as well as by unstable potassium-magnesium salts. That phase of the diagenesis/metamorphism should have been associated with the development of the high-temperature variaty of $\beta$-boracite and probably of szaibelyite.

In contrast to boracite, the origin of congolite was not directly associated with $\mathrm{K}-\mathrm{Mg}$ salts. Congolite typically occur regularly in pure rock salts, jointly with the Pegmatite Anhydrite, at a distance of several metres from the bottom and top of that layer. This rock is certainly directly associated with congolite recrystallisation in that part of the deposit. The Pegmatite Anhydrite is strongly affected by tectonics, displaying cracked and displaced layer, with a thickness from $20 \mathrm{~cm}$ to $1 \mathrm{~m}$. The rock is intersected by irregular veins and lenses of epigenetic halite, making up from several to about 30 vol.\%. Therefore, we can suppose that the cracked and porous Pegmatite Anhydrite layer represents the migration path for the hot borate brines from which congolite crystallised in the surrounding rocks during cooling. The lower K3 potash salt bed may have been the source of the borate solutions. Migration of solutions in the cracked and locally karstified salt diapir must have been quite frequent.

Specific properties of boracite and congolite are the premises for the recognition of the thermal history of salt domes. Precise determination of the minimum temperature required for the development of the high-temperature varieties of $\beta$-boracite $\left(\sim 270^{\circ} \mathrm{C}\right)$ and $\beta$-congolite $\left(\sim 338^{\circ} \mathrm{C}\right)$ defines the temperatures occurring in at least in some parts of the salt dome.

The source of such high temperatures needs to be considered. Such classical factors as pressure and temperature gradients, being key factors that cause plastification and halokinetic movement of salt masses as well as the transformations of most salt minerals, could not raise temperatures above $200^{\circ} \mathrm{C}$. Energy provided as a result of friction forces developing in the relocating salt masses also does not seem to be an adequate mechanism to generate a temperature in the range of $300-400^{\circ} \mathrm{C}$, mainly owing to the very good thermal conductivity of salt rocks and a lack of insulating layers, both within the salt dome and at the contact zone with the surrounding rocks. The energy generated by the decomposition of radioactive elements, such as potassium $\mathrm{K}^{40}$ in sylvine and carnallite may not be sufficient due to the scarcity of these isotopes.

We may, however, assume that these factors exert a combined regional influence on the thermal conditions occurring in salt domes.

Therefore, the main sources of additional energy causing local temperature increases to several hundred ${ }^{\circ} \mathrm{C}$ may be sought in the deep pre-Zechstein strata, and the energy release and distribution should be associated with the diapir uplift processes. The tectonic movements of the pre-Zechstein strata of the Mid-Polish Trough in subsequent orogenic stages, starting from the Triassic, were the primary factors causing halokinetic activities of salt masses (e.g., Znosko, 1957; Krzywiec, 2004). Deep stratal cracking and tectonic dislocations accompanying those movements may have been favourable for the migration of hot brines to the upper portions of the salt dome.

The presence of intrusions under some salt deposits, e.g. the basalt dyke under the potash deposit in Buggingen, Upper Rheinland (Braitsch et al., 1964), dolerite intrusions in the Cambrian carbonate-evaporite deposit in the East Siberian saliferous basin (Knipping, 1989; Grishina et al., 1992), indicate the possibility of occurrence of such thermal activities. Unfortunately, our knowledge of the structure of deep sections of the salt domes in the Polish Lowlands, and especially of the nature of the domal contact with pre-Zechstein basement, is limited because of a lack of drilling data. The presence of igneous phenomena under the Mid-Polish Trough may be excluded, although hydrothermal activity increasing heat flow to the higher sections of salt domes is quite probable. In addition, the latter activity is the only realistic supposition explaining the occurrence of high temperatures, of some $300-350^{\circ} \mathrm{C}$ and possibly even higher, in certain sections of the salt diapir.

\section{CONCLUSIONS}

The borate crystals of the Kłodawa salt dome are paramorphoses of low-temperature varieties of $\alpha$-boracite, with orthorhombic symmetry, and of $\alpha$-congolite, with rhombohedral symmetry, after high-temperature $\beta$ varieties of both minerals, which had regular symmetry. Thermal studies of these minerals indicated reversible phase transitions taking place close to the temperatures indicated by other authors (Ito et al., 1951; Sueno et al., 1973; Schmid and Tippmann, 1978; Burns and Carpenter, 1996, 1997).

Boracite crystals change their symmetry from orthorhombic to cubic at ca. $270^{\circ} \mathrm{C}$, and in the case of congolite at $339^{\circ} \mathrm{C}$. During cooling of the crystals, the transformation of the symmetries to lower temperature forms occurred at the same temperatures. The phase transition temperatures of boracite and congolite clearly indicate that the rocks of the Kłodawa salt dome, or at least some of the dome sections, were heated to much higher temperatures (exceeding $338^{\circ} \mathrm{C}$ ) than those resulting from the geothermal gradient only. The sources of such high temperatures may be identified in tectonic activities affecting the deep pre-Zechstein strata and the resulting hydrothermal events. The tectonic relocations within and outside the salt dome became specific thermal paths within such fractured rigid rocks as anhydrite or clay-salt deposits (zubers), as well as the salt masses themselves being good heat carriers. In addition to hydrothermal solutions, the primary brines enclosed in the salt dome and the solutions developed as a result of post-depo- 
sitional dehydration of evaporites were the main heat carriers. Hot solutions, pressed out from deep sections of the salt dome, were subjected to relocation through fissures in the diapir and penetrated even the highest sections of the dome, becoming the main reason for the diagenetic and metamorphic transformations of salt rocks and minerals.
Acknowledgements. The investigations were supported by the AGH University of Science and Technology in Kraków, the grant No. 11.11.140.320. Comments from reviewers J. Garcia-Veigas, J. Parafiniuk and M. Schramm helped us to improve the manuscript greatly.

\section{REFERENCES}

Borchert, H., Muir, R.O., 1964. Salt Deposits. The Origin, Metamorphism and Deformation of Evaporites. D. Van Nostrand Company, LTD. London.

Braitsch, O., 1971. Salt Deposits Their Origin and Composition. Springer Verlag, New York.

Braitsch, O., Gunzert, G., Wimmenauer, W., Thiel, R., 1964. Über ein Datolithvorkommen am Basaltkontakt im Kaliwerk Buggingen (Südbaden). Beiträge zur Mineralogie und Petrographie, 10: 111-124.

Burliga, S., 2011. The oldest stratigraphic units in the Kłodawa salt dome. In: Storage and disposal in salt workings - present day and future of salt mining. XVI International Salt Symposium "Quo Vadis Sal", Toruń, Poland: 11-12 (abstract).

Burliga, S., Kolonko, P., Misiek, G., Czapowski, G., 1995 Kłodawa salt mine. In: Upper Rotliegend - Zechstein: terrestrial - marine sedimentary succession in Polish Permian Basin (ed. J. Małecka): 45-54. XIII International Congress on Carboniferous-Permian, August 28 - September 2, 1995, Guide to Excursion A3, Kraków, Poland.

Burns, P.C., Carpenter, M.A., 1996. Phase transitions in the series boracite-trembathite-congolite: phase relations. Canadian Mineralogist, 34: 881-892.

Burns, P.C., Carpenter, M.A., 1997. Phase transitions in the series boracite-trembathite-congolite: an infrared spectroscopic study. Canadian Mineralogist, 35: 189-202.

Charysz, W., 1973. Zechstein stage of Younger Salts (Z3) in Kujawy region) (in Polish with English summary). Prace Geologiczne, 75.

Dadlez, R., 1997. Epicontinental basins in Poland: Devonian to Cretaceous - relationship between the crystalline basement and sedimentary infill. Geological Quarterly, 41 (4): 419-432.

Dadlez, R., Narkiewicz, M., Stephenson, R.A., Visser, M.T.M., Wees, J-D. van, 1995. Tectonic evolution of the Mid-Polish Trough: modelling implications and significance for central European geology. Tectonophysics, 252: 179-195.

Dadlez, R., Marek, S., Pokorski, J., eds., 1998. Palaeogeographic Atlas of epicontinental Permian and Mesozoic in Poland (1:2 500 000) (in Polish). Państwowy Instytut Geologiczny, Warszawa.

Dowty, E., Clark, J.R., 1973. Crystal-structure refinements for orthorhombic boracite, $\mathrm{Mg}_{3} \mathrm{ClB}_{7} \mathrm{O}_{13}$, and a trigonal, iron-rich analogue. Zeitschrift für Kristallographie, 138: 64-99.

Fijał, J., 1970. On the occurrence of ascharite in the Kłodawa salt dome. Mineralogia Polonica, 1: 29-35.

Fijał, J., 1973. Accessory minerals of the Kujawy salt deposits (in Polish with English summary). Prace Mineralogiczne, 33: 1-56.

Garlicki, A., Szybist, A., 1986. Saline deposits of Polish Zechstein with potash salt (in Polish with English summary). Gospodarka Surowcami Mineralnymi, 2: 391-404.

Grishina, S., Dubessy, J., Kontorovich, A., Pironon, J., 1992. Inclusions in salt beds resulting from thermal metamorphism by dolerite sills (eastern Siberia, Russia). European Journal of Mineralogy, 4: 1187-1202.

Grube, G., Bräuning, W., 1938. Über die Entwässerung von Magnesiumchloridhexahydrat und Carnallit. Elektrochemie, 44: 134-143.

Hanczke, T., 1969. Mineralogy and petrography of the Zechstein salt in Kłodawa mine (in Polish with English summary). Prace Muzeum Ziemi, 16: 3-52.
Ito, T., Morimoto, N., Sadanaga, R., 1951. The crystal structure of boracite. Acta Crystallographica, 4: 310-316.

Kern, H., Franke, J.H., 1986. Carnallit - Thermisches und thermochemisches Verhalten in Endlagersalzstöcken. Zeitschrift der Deutschen Geologischen Gesellschaft., 137: 1-27.

Knipping, B., 1989. Basalt Intrusions in Evaporites. Lecture Notes in Earth Sciences, 24. Springer, Berlin-Heidelberg-New York-Tokyo.

Krzywiec, P., 2004. Triassic evolution of the Kłodawa salt structure: basement-controlled salt tectonics within the Mid-Polish Trough (Central Poland). Geological Quarterly, 48 (2): 123-134.

Krzywiec, P., 2006. Structural inversion of the Pomeranian and Kuiavian segments of the Mid-Polish Trough - lateral variations in timing and structural style. Geological Quarterly, 50 (1): 151-168.

Łaszkiewicz, A., Langier-Kuźniarowa, A., 1966. The application of the thermal analysis to the investigation of salt rocks (in Polish with English summary). Archiwum Mineralogiczne, 26: 131-160.

Schmid, H., Tippmann, H., 1978. Spontaneous birefringence in boracites - measurements and applications. Ferroelectrics, 20: 21-36.

Stańczyk-Stasik, I., 1976. Les dépots èpigénétiques dans les mines de sel de la région de Kujawy (in Polish with French summary). Prace Geologiczne, 90: 1-64.

Sueno, S., Clark, J.R., Papike, J.J., Konnert, J.A., 1973. Crystal-structure refinement of cubic boracite. American Mineralogist, 58: 691-697.

Tarka, R., 1992. Tectonics of some salt deposits in Poland based on mesostructural analyses (in Polish with English summary). Prace Państwowego Instytutu Geologicznego, 137: 1-47.

Toboła, T., Natkaniec-Nowak, L., ed., 2008. Sole niebieskie w wysadzie kłodawskim (in Polish). Uczelniane Wyd. Nauk.-Dydaktyczne AGH: 1-136.

Trusheim, F., 1960. Mechanism of salt migration in northern Germany. AAPG Bulletin, 44: 1519-1540.

Wachowiak, J., 1998. Studium mineralogiczne skał chemicznych i silikoklastycznych wysadu solnego Kłodawa (in Polish). Ph.D. thesis. Arch. AGH, Kraków.

Wachowiak, J., 2010. Mineral levels in Upper Permian (Zechstein) salts of the Kłodawa salt diaper as a tool for lithostratigraphic correlation (in Polish with English summary). Geologia, 36: 367-393.

Wachowiak, J., Pieczka, A., 2012. Congolite and trembathite from the Kłodawa Salt Mine, Central Poland: records of the thermal history of the parental salt dome. Canadian Mineralogist, 50: 1387-1399.

Werner, Z., Poborski, J., Orska, J., Bąkowski, J., 1960. A geological and mining outline of the Kłodawa salt deposit (in Polish with English summary). Prace Instytutu Geologicznego, 30: 467-512.

Yarzhemskiy, J.J., 1984. Boronosnyye galogiennyye porody (in Russian). Izdatielstwo "Nauka“ Akademia Nauk SSSR, Novosibirsk: $1-80$.

Znosko, J., 1957. Uplift of the Kłodawa salt dome during the Jurassic, and its influence upon the formation of the lumachel rocks (in Polish with English summary). Geological Quarterly, 1 (1): 90-103. 